\title{
Genetic Variability and Relationship of Closely Related Spanish Traditional Cultivars of Tomato as Detected by SRAP and SSR Markers
}

\author{
Juan J. Ruiz and Santiago García-Martínez \\ Department of Applied Biology, Universidad Miguel Hernández, Orihuela 03312, Spain \\ Belén Picó \\ Department of Biotechnology, Universidad Politécnica deValencia, Valencia 46022, Spain \\ Muquiang Gao and Carlos F. Quiros \\ Department of Vegetable Crops, University of California, Davis, CA 95616
}

\begin{abstract}
ADDITIONAL INDEX WORDS. microsatellites, germplasm, molecular markers, diversity
ABSTRACT. We studied the genetic variability of some traditional tomato (Lycopersicon esculentum L. Mill.) cultivars of Spain, and established their relationships using both simple sequence repeats (SSR) and sequence related amplified polymorphism (SRAP) markers. These included cultivars from different locations of three main types, Muchamiel, De la pera, and Moruno. Additionally we tested two other local cultivars, 'Valenciano' and 'Flor de Baladre', plus a small sample of commercial cultivars and a few wild species. Both types of markers resolved the cultivars from different groups, but SSR failed to distinguish some of those classified under the same group. All the De la pera cultivars clustered together by genetic similarity with the SRAP markers. The other traditional cultivars, which are grown in a wider geographic range, formed a more diffuse group, which included the commercial cultivar Roma. The Mexican cultivar Zapotec, a breeding line, and the virus-resistant commercial hybrid 'Anastasia' were the most distant of all the cultivars. The latter hybrid had higher similarity to the wild species due to introgressed segments from them carrying the resistance genes. Similar results were observed for SSR markers but with a lower level of resolution. This information would be useful to facilitate tomato germplasm conservation and management efforts.
\end{abstract}

The low genetic diversity of modern tomato cultivars is reflected by a poor level of polymorphism for proteins, isoenzymes, and most types of DNA markers (Bredemeijer et al., 1998). For DNA sequence data, Nesbitt and Tanksley (2002) reported a near absence of polymorphism in genes probably involved in tomato domestication, among two modern processing tomatoes and two heirloom cultivars, one with extremely large fruit and one with bell-pepper-shaped fruit.

Spain and Italy were the first European countries where the tomato acquired commercial importance, after its probable domestication in Mexico. Following its introduction to the Old World, a wide range of local cultivars was developed, organoleptic quality being one of the main selection criteria. Tomato is the main vegetable crop in Spain, and furthermore, it is the horticultural crop with the highest commercial value (Nuez et al., 2002). Southeastern Spain is the most important area of fresh-market tomato production in the country. Although this production is almost exclusively based on modern hybrid cultivars, there are still several traditional local cultivars renowned for their high quality. In fact, in local markets, these traditional cultivars sell for three to six times the price of the hybrid cultivars. This is the case for two types of local cultivars, the Muchamiel and the De la pera type. There is also variability within type; each locality seems to have developed its own cultivar or cultivated form. In fact, strong differences have been found for micronutrient contents and some quality parameters among and within these types of cultivars, suggesting the presence of a certain degree of

Received for publication 28 May 2004. Accepted for publication 13 June 2004. This research was supported in part by the Comisión Interministerial de Ciencia y Tecnología (CICYT) through the project AGL2002-03329. S. García-Martínez is a fellow of the Ministerio de Educación, Cultura y Deporte of Spain. genetic diversity (Ruiz et al., 2004). We are starting a program to introgress several genetic resistance genes into local cultivars of the Muchamiel and De la pera types, but at the same time trying to keep the diversity within these tomato types. In order to facilitate the conservation and management of the extant diversity, it would be useful to use molecular markers to measure it. Simple sequence repeat (SSR) or microsatellite are short [mostly 2-4 base pairs (bp)] tandem repeats of DNA sequences. They show a high level of polymorphism because the number of repeat motifs may vary significantly between different genotypes. SSR markers are becoming the preferred molecular markers in crop breeding because of their properties of genetic co-dominance, high reproducibility, and multiallelic variation. In tomato, several studies have investigated the usefulness of SSR as molecular markers and have determined their level of polymorphism and information content for use in cultivar identification (Bredemeijer et al., 1998, 2002, He et al., 2003; Smulders et al., 1997). SSR markers are useful to distinguish tomato cultivars belonging to very different types, and most of them containing gene introgressions from several wild Lycopersicon L. species (Bredemejer et al., 2002; He et al., 2003). Therefore, it is not clear whether these SSR markers would be useful to detect differences among closely related cultivars or genotypes. SRAP ( $\mathrm{Li}$ and Quiros, 2001) is a simple and reliable polymerase chain reaction (PCR)-based marker system, designed to detect mostly coding sequence polymorphisms. Combinations of two types of primers are employed, the forward primer amplifies preferentially exonic regions, and the reverse primer amplifies preferentially intronic regions and regions with promoters. This system has been applied in some crops (Ferriol et al., 2004; Li and Quiros, 2001; Ruiz et al., 2001). It will be desirable to use the tomato as a model to apply such a system, which does not require previous development. The goal 
of this study was to investigate the variability among and within some closely related traditional tomato cultivars, and to establish relationships among them. We compare the usefulness of SSR and SRAP markers for this purpose.

\section{Materials and Methods}

Plant material. The plant accessions used in this study are listed in Table 1. The Muchamiel type includes several cultivars, differing mainly in fruit size and ribbing intensity. The De la pera type includes several cultivars grown and appreciated in a narrower area than the Muchamiel type. Tomate Moruno is a rather ambiguous denomination for a big-sized tomato with a dark red color, which is mainly cultivated in different mountain areas of southern and eastern Spain. Two other types were included with only one representative, the Flor de Baladre, a type of cultivar only grown in Murcia, and the Valenciano, mainly cultivated in the orchards near the town of Valencia. The cultivar Zapotec, claimed as coming from the Oaxaca region in Mexico, was also included.

We have been working mainly with cultivars of the De la pera and the Muchamiel types, and have found important differences even among cultivars of the same type, for agronomic characteristics as yield and fruit weight, and also for micronutrient contents, aroma volatiles contents, or sensory panel appreciations (Alonso et al., 2003; Ruiz et al., 2004). These types of tomato cultivars usually show a strong genotype $\times$ environment effect, in contrast with the more uniform behavior of the hybrid cultivars.
Single accessions of the species L. esculentum var. cerasiforme (Dunal) Alef., L. pimpinellifolium (Jusl.) Mill., L. chilense Dunal, L. cheesmanii Riley, and L. peruvianum (L.) Mill. were use as outgroups and to compare the levels of variability among cultivated and wild species.

DNA Extraction. A modified version of the Dellaporta et al. (1983) method was used to extract genomic DNA. A volume of $200 \mu \mathrm{L}$ of extraction buffer (Tris- $\mathrm{HCl} 0.1 \mathrm{M}$; EDTA $0.05 \mathrm{M}$; $\mathrm{NaCl} 0.5 \mathrm{M}$ ) was added to $\approx 0.1 \mathrm{~g}$ of fresh leaf tissue in a $1.5-\mathrm{mL}$ eppendorf tube, and its content crushed with a small plastic bar. The content was homogenized after adding another $300 \mu \mathrm{L}$ of extraction buffer. A volume of $35 \mu \mathrm{L}$ of sodium dodecyl sulfate (20\%) was added to the tubes and incubated at $65^{\circ} \mathrm{C}$ for $5 \mathrm{~min}$. Then, $130 \mu \mathrm{L} 5 \mathrm{~m}$ potassium acetate was added, after $5 \mathrm{~min}$ of incubation at room temperature, the tubes were centrifuged at $14,000 g_{\mathrm{n}}$ for $10 \mathrm{~min}$. The supernatant was transferred into a new tube and the DNA precipitated with one volume of 2-propanol and $60 \mu \mathrm{L} 3 \mathrm{~m}$ sodium acetate. After $10 \mathrm{~min}$ of incubation at room temperature, the tubes were centrifuged again for $10 \mathrm{~min}$. The DNA was then washed with $70 \%$ ethanol and dissolved in water and quantified.

DNA was isolated from four seedlings of each accession and used for PCR amplification, in order to determine whether differences existed in SRAP patterns between individual plants. After a preliminary analysis, DNA extractions of the four plants were mixed, and the bulks were used for further analysis. All the SSR analysis were conducted using the same four plants per accession. In order to confirm the polymorphisms detected, PCR

Table 1. Origin of the tomato cultivars and wild species analyzed in the present study.

\begin{tabular}{|c|c|c|c|}
\hline Type & Code & No. $^{z}$ & Origin \\
\hline \multirow[t]{5}{*}{ Muchamiel } & Much4 & 6 & Orihuela, Alicante \\
\hline & Much11 & 7 & Murcia \\
\hline & Much18 & 8 & Muchamiel, Alicante \\
\hline & Much29 & 9 & Huércal-Overa, Almería \\
\hline & Much30 & 10 & San Bartolomé, Alicante \\
\hline \multirow[t]{5}{*}{ De la pera } & Pera5 & 1 & Benejúzar, Alicante \\
\hline & Pera16 & 2 & Cox, Alicante \\
\hline & Pera19 & 5 & La Campaneta, Alicante \\
\hline & Pera22 & 3 & La Campaneta, Alicante \\
\hline & Pera25 & 4 & Rafal, Alicante \\
\hline \multirow[t]{4}{*}{ Moruno } & Mor207 & 12 & Sierra de Albacete \\
\hline & Mor208 & 13 & Hontanaya, Cuenca \\
\hline & Mor209 & 14 & Hontanaya, Cuenca \\
\hline & Mor232 & 15 & Puebla de Don Fabrique, Granada \\
\hline Valenciano & Valenciano & 11 & Albuixec, Valencia \\
\hline Flor de Baladre & Baladre & 16 & Murcia \\
\hline Processing tomato & Roma & 17 & Battle Seeds \\
\hline Zapotec & Zapotec & 19 & Mexico \\
\hline Breeding line & EPSO42 & 24 & Escuela Politécnica Superior de Orihuela \\
\hline Commercial $\mathrm{F}_{1}$ hybrid & Anastasia & 18 & Seminis Vegetable Seeds \\
\hline \multicolumn{4}{|l|}{ Wild species } \\
\hline \multicolumn{4}{|l|}{ L. esculentum var. } \\
\hline cerasiforme LA2617 & CerLA2617 & & TGRCy \\
\hline L. cheesmanii LA422 & CheLA422 & 22 & TGRC \\
\hline L. pimpinellifolium LA2853 & PimLA2853 & 23 & TGRC \\
\hline L. peruvianum LA2744 & PerLA2744 & 20 & TGRC \\
\hline L. chilense LA458 & ChiLA458 & 21 & TGRC \\
\hline
\end{tabular}

zNumbers correspond to numbered lanes of Fig. 1.

yTomato Genetic Resources Center, Univ. of California, Davis. 
amplifications were repeated using the same DNA samples in independent experiments.

SRAP ANALYSIS. We used the SRAP protocol as reported by $\mathrm{Li}$ and Quiros (2001) and Li et al. (2003). In this assay, 26 different primer combinations were employed. The following primers were used: CE8, DC1, EM1, EM2, EM7, EM8, GA5, GA30, GA33, GA34, ME1, ME2, ME3, ME4, ME7, ME8, ME10, OD3, OD13, OD15, OD17, OD30, OD34, PM19SA14 (Li and Quiros, 2001; Li et al., 2003; Ruiz et al., 2001). The forward primer was labeled with IRDye 800 or IRDye 700. The PCR products were ran in a LI-COR sequencer IR2, model 4200. (LI-COR, Lincoln, Nebr.). Fragments between 150 and 500 bp were visually scored as present or absent (Fig. 1).

SSR ANALYSIS. For SSR analysis we followed the protocol described by Smulders et al. (1997). Among the relatively high number of SSR loci already reported in tomato, we selected 10 of the SSR previously selected by Smulders et al. (1997) and Bredemeijer et al. (1998). SSR markers were selected on the basis of easy amplification, presence of polymorphisms among the L. esculentum cultivars used by these authors and the quality of electrophoretic patterns (Table 2).

PCR products were prepared for polyacrylamide gel electrophoresis (PAGE) by adding an equal volume of formamide, containing $10 \mathrm{~mm} \mathrm{NaOH}$ and $0.05 \%$ bromphenol blue, to the reaction mixtures. After denaturation at $80{ }^{\circ} \mathrm{C}$ for $5 \mathrm{~min}$ followed by quenching on ice, the samples were analyzed on vertical gels (12\% polyacrylamide, $7 \mathrm{~m}$ urea, Tris-borate buffer). The DNA bands were visualized by silver staining, and the sizes of the PCR products were determined by comparison to the molecular weight marker Roche VI, or by comparison to SSR markers amplified in genotypes with known allele sizes (Bredemeijer et al., 1998; Smulders et al., 1997).

DATA ANALYSIS. For both SRAP and SSR markers, genetic similarities among genotypes were calculated according to the Nei and $\mathrm{Li}(1979)$ using the similarity coefficient $\mathrm{S}_{i j}=2 \mathrm{a} /(2 \mathrm{a}+\mathrm{b}+\mathrm{c})$, where $\mathrm{S}_{i j}$ is the similarity between two individuals $i$ and $j$; $\mathrm{a}$ is the number of shared bands; $b$ is the number of bands exclusive of $i$ and $c$ is the number of bands exclusive of $j$. The similarity matrix was first subjected to cluster analysis by the unweighted pair-group method (UPGMA; Sneath and Sokal, 1973), and a tree was constructed using NTSYS pc v. 2.0.2 (Rohlf, 1998). The reliability and robustness of the dendrograms were tested by bootstrap analysis with 1000 replications to assess branch support using PHYLIP 3.6 software (Felsenstein, 1993). The similarity matrix was also used in a principal coordinates analysis (PCoA) to obtain graphical representations of the relationship structure of the accessions. A diversity index was calculated using the formula $\mathrm{D}=1-\sum \mathrm{P} i^{2}$ where $\mathrm{P} i$ is the frequency of the $i$ th allele in the accessions examined.

\section{Results and Discussion}

\section{Variability within accessions}

SRAP. Initially four individual plants of each accession were analyzed using 13 SRAP combinations. Of the 178 amplified fragments, $98(55.1 \%$ ) were polymorphic among all Lycopersicon accessions, and only 14 (7.8\%) were polymorphic among the $L$. esculentum accessions. Polymorphism within cultivars was very low. We found the same patterns between individual plants for the majority of De la pera cultivars ('Pera5', 'Pera16', 'Pera22', and 'Pera25'). Only cultivar Pera19 displayed a polymorphism of $1.6 \%$. Cultivars of the Muchamiel and Moruno types also

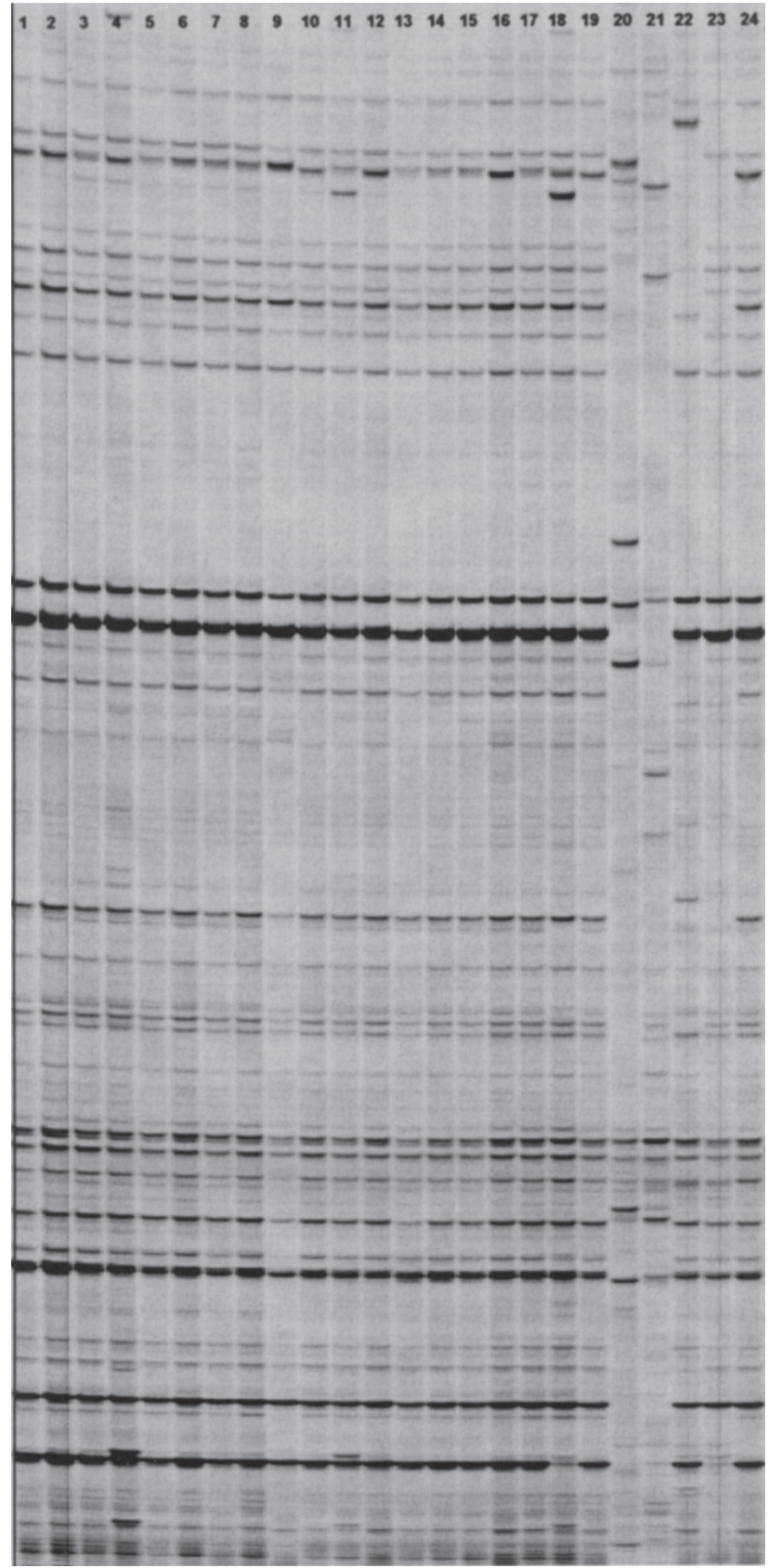

Fig. 1. Part of a gel image $(\approx 1 / 3)$ obtained with the sequence related amplified polymorphism (SRAP) primers ME2-EM1 and visualized in a LI-COR system. Lanes 1-19 and 24 correspond to tomato cultivars, and lines 20-23 correspond to wild Lycopersicon species (see Table 1).

showed some intra-cultivar variability, with the exception of cultivar Much4, which was monomorphic. The polymorphism within these cultivars was always lower than $4 \%$. Although De la pera cultivars seem to be homogeneous, the variability found within the Muchamiel and Moruno cultivars may be due to the lower degree of selection and breeding in these types. Uniformity is not a strict requirement in this kind of cultivars, which are usually grown in small fields and destined to self-consumption or to local markets.

SSR. No differences in SSR profiles among the four individual plants of each cultivar were found. Our results are similar to those of Bredemeijer et al. (1998). They found no differences in SSR profiles among nine individual plants of 'Moneymaker' and the hybrid 'Calypso' with the two most discriminative microsatellites. 
Table 2. Set of simple sequence repeats (SSR) primers used in the present study.

\begin{tabular}{|c|c|c|c|c|}
\hline SSR & Repeat $^{z}$ & $\begin{array}{l}\text { No. of alleles } \\
\text { in the present study }\end{array}$ & Primers & $\begin{array}{l}\text { PCR annealing } \\
\text { temp }\left({ }^{\circ} \mathrm{C}\right)\end{array}$ \\
\hline LE20592 & $(\mathrm{TAT})_{15-1}(\mathrm{TGT})_{4}$ & 5 & $\begin{array}{l}\text { 5'-CTGTTTACTTCAAGAAGGCTG-3' }^{\prime} \\
\text { 5'-ACTTTAACTTTATTATTGCCACG-3' }\end{array}$ & 5 \\
\hline LE21085 & $(\mathrm{TA})_{2}(\mathrm{TAT})_{9-1}$ & 3 & $\begin{array}{l}5^{\prime} \text {-CATTTTATCATTTATTTGTGTCTTG-3 } \\
5^{\prime} \text {-ACAAAAAAAGGTGACGATACA-3' }\end{array}$ & 50 \\
\hline LECHI3 & $(\mathrm{TA})_{6-1}(\mathrm{GA})_{4}$ & 2 & $\begin{array}{l}\text { 5'-TAACAATCAAAAGAACTTCGC-3' } \\
\text { 5'-ATCCCCTTATTGATTACATCC-3' }^{\prime}\end{array}$ & 55 \\
\hline LEEF1Aa & $(\mathrm{TA})_{8}(\mathrm{ATA})_{9}$ & 9 & $\begin{array}{l}\text { 5'-AAATAATTAGCTTGCCAATTG-3' } \\
\text { 5'-CTGAAAGCAGCAACAGTATTT-3' }^{\prime}\end{array}$ & 55 \\
\hline LELE25 & $(\mathrm{TA})_{13-1}$ & 4 & $\begin{array}{l}\text { 5'-TTCTTCCGTATGAGTGAGT-3' } \\
\text { 5'-CTCTATTACTTATTATTATCG-3' }\end{array}$ & 50 \\
\hline LELEUZIP & $(\mathrm{AAG})_{6-1} \mathrm{TT}(\mathrm{GAT})_{7}$ & 3 & $\begin{array}{l}\text { 5'-GGTGATAATTTGGGAGGTTAC-3' } \\
5^{\prime} \text {-CGTAACAGGATGTGCTATAGG-3' }\end{array}$ & 55 \\
\hline LEMDDNa & $(\mathrm{TA})_{9}$ & 6 & $\begin{array}{l}\text { 5'-ATTCAAGGAACTTTTAGCTCC-3' } \\
5^{\prime} \text {-TGCATTAAGGTTCATAAATGA-3' }\end{array}$ & 55 \\
\hline LESSF & $(\mathrm{CCCCA})_{4}$ & 6 & $\begin{array}{l}\text { 5'-TACGCTCTCAAGTACCGTAAG-3' } \\
\text { 5'-CCTACATTGACATGACCAAAT-3' }\end{array}$ & 55 \\
\hline LESSRPSPGb & $(\mathrm{C})_{16}$ & 7 & $\begin{array}{l}\text { 5'-AACATTAGTTTGATTGGATGG-3' } \\
\text { 5'-TTAAACTTTGCTTGACTTTCC-3' }\end{array}$ & 50 \\
\hline LEWIPIG & $(\mathrm{CT})_{8-1}(\mathrm{AT})_{4}$ & 5 & $\begin{array}{l}\text { 5'-GAGTCAAAGTTTGCTCACATC-3' } \\
5^{\prime} \text {-CTCTTCTGAACTTGCTTTGAG-3' }\end{array}$ & 55 \\
\hline
\end{tabular}

${ }^{\mathrm{z} A}$ minus-sign indicates deviation from perfect repeat, e.g., (TA $)_{6-1}$ is a (TA) ${ }_{6}$ repeat with one internal base pair different from the repeat (Smulders et al., 1997).

Thus, the scarce intra-cultivar variability detected by the SRAP marker system was not detectable by the selected SSR markers. Although microsatellites regions present higher variability than other genomic regions, the different results could be explained by the number of analyzed loci, that was much higher with SRAP than with SSR markers.

\section{Variability among accessions}

SRAP. After conforming the extremely low levels of polymorphism within the analyzed local cultivars, a second analysis was carried out using the DNA bulks for each accession. A total of 384 fragments were amplified using 26 primer combinations. Two hundred and forty two (66\%) were polymorphic among the Lycopersicon accessions, and $58(15.1 \%)$ among L. esculentum cultivars. The degree of polymorphism within each cultivar type was variable (Table 3 ). The De la pera type was the less variable $(4.9 \%)$, followed by Muchamiel type $(5.5 \%)$, and Moruno type (7\%). All cultivars could be distinguished with the SRAP markers used, but no cultivar or type-specific fragments were detected, except for a fragment that was absent only in all De la pera cultivars.

SSR. All the 10 SSR markers showed polymorphisms among the genotypes evaluated. The number of alleles amplified in all the accessions varied between nine for marker LEEF1Aa and two for marker LECHI3, with a mean value of five alleles. The values of the diversity index varied between 0.25 and 0.76 , similar values than those found by other authors. However, if we consider only the cultivated accessions, the diversity index ranged from 0 to 0.61 (mean $=0.28$ ), being the mean value for the wild accessions 0.60. The SSR markers LE21085, LECHI3, and LEWIPIG were monomorphic among all the cultivated cultivars. The same allele for marker LE20592 was shared by all the cultivated cultivars, except for the hybrid 'Anastasia', which was heterozygous. Markers LEEF1Aa and LESSRPSPGb were monomorphic among De la pera cultivars and polymorphic among the Muchamiel and the Moruno types, whereas marker LEMDDNa was monomorphic among the Muchamiel and Moruno types and polymorphic among De la pera cultivars. Marker LELEUZIP was monomorphic within Muchamiel and De la pera types and polymorphic among Moruno cultivars. Only two microsatellite markers showed alleles specific for cultivated tomato types: marker LELE25 showed an allele only present in all De la pera cultivars (and in the accession of L. esculentum var. cerasiforme LA2617), and marker LESSF showed an allele specific for Valenciano (again only shared with cerasiforme LA2617). The fact that these two tomato type-specific alleles are only found in cerasiforme reinforces its close relationship with the cultivated tomato. In addition, the alleles that were monomorphic in all the cultivated cultivars for markers LE21085, LECHI3, and LEWIPIG were also only present in cerasiforme LA2127 among the wild accessions. This result is in agreement with historical and linguistic studies suggesting that the cultivated tomato was most likely selected from wild forms of cerasiforme (Jenkins, 1948; Rick, 1976). However, phylogenetic/diversity studies based on isozymes and DNA polymorphism, and comparative sequencing have not clarified this issue (Alvarez et al., 2001; Nesbitt and Tanksley, 2002). According to Nesbitt and Tanksley (2002), extant accessions of L. esculentum var. cerasiforme appear to be an admixture of wild and cultivated tomatoes rather than a transitional step from wild to domesticated tomatoes, suggesting that the subspecies may be derived from hybridization between L. esculentum domesticates and L. pimpinellifolium wild forms. Our limited study do not support this idea, since cerasiforme shares some specific SSR tomato alleles, and shares not a single allele with $L$. pimpinellifolium. However, a more comprehensive accession survey will be necessary to settle this issue.

The three main Spanish cultivars types analyzed, Muchamiel, De la pera, and Moruno, could be differentiated using only two SSR markers (Table 4). An additional SSR marker, LESSF, was needed to specifically identify the cultivar Valenciano. This set of SSR also separate 'Baladre' from almost all the others types, but it is impossible to differentiate it from some of the Moruno cultivars. 
Table 3. List of sequence related amplified polymorphism (SRAP) primer pairs used. The number of fragments scored, the number of polymorphic fragments among all Lycopersicon accessions, and the number of polymorphic fragments among cultivated tomato accessions per each primer pair are presented.

\begin{tabular}{|c|c|c|c|c|c|c|c|}
\hline $\begin{array}{l}\text { Primer } \\
\text { combination }\end{array}$ & $\begin{array}{c}\text { No. of } \\
\text { fragments }\end{array}$ & $\begin{array}{l}\text { Polymorphic } \\
\text { fragments } \\
\text { (all } \\
\text { accessions) }\end{array}$ & $\begin{array}{l}\text { Polymorphic } \\
\text { fragments } \\
\text { (cultivated } \\
\text { accessions) }\end{array}$ & $\begin{array}{c}\text { Primer } \\
\text { combination }\end{array}$ & $\begin{array}{c}\text { No. of } \\
\text { fragments }\end{array}$ & $\begin{array}{l}\text { Polymorphic } \\
\text { fragments } \\
\text { (all } \\
\text { accessions) }\end{array}$ & $\begin{array}{c}\text { Polymorphic } \\
\text { fragments } \\
\text { (cultivated } \\
\text { accessions) }\end{array}$ \\
\hline$\overline{\text { DC1z-OD30 }}$ & 20 & 16 & 1 & GA5-CE-8 & 15 & 10 & 2 \\
\hline DC1-OD34 & 23 & 16 & 5 & GA5-ME4 & 11 & 9 & - \\
\hline EM1-ME-1 & 18 & 10 & 1 & GA5-PM19 & 13 & 11 & 1 \\
\hline EM1-OD17 & 22 & 10 & - & ME2-EM1 & 49 & 30 & 9 \\
\hline EM2-ME1 & 28 & 20 & 5 & ME2-EM2 & 6 & 4 & 1 \\
\hline EM2-ME3 & 4 & 3 & 2 & ME2-EM7 & 4 & 3 & 2 \\
\hline EM2-ME4 & 9 & 5 & 4 & ME2-EM8 & 10 & 8 & 2 \\
\hline EM2-ME7 & 7 & 4 & 3 & ME2-GA30 & 12 & 8 & $3 y$ \\
\hline EM2-ME8 & 9 & 4 & 2 & ME-2-GA34 & 24 & 14 & 3 \\
\hline EM2-ME10 & 11 & 5 & 1 & ME2-OD3 & 13 & 9 & - \\
\hline EM2-OD13 & 11 & 9 & 1 & ME8-GA33 & 6 & 4 & 1 \\
\hline EM2-OD15 & 12 & 6 & 1 & SA14-GA33 & 11 & 9 & 1 \\
\hline EM2-OD34 & 11 & 8 & 2 & SA14-ME8 & 25 & 18 & 5 \\
\hline
\end{tabular}

zThe forward primers were labeled with IRDye (IRDye 800 or IRDye 700) and visualized in a LI-COR sequencer IR2.

yFragment absent only in cultivars of De la pera type.

Table 4. Simple sequence repeat (SSR) markers needed to differentiate among the main traditional cultivar types of tomato assayed.

Cultivar type

\begin{tabular}{|c|c|c|c|c|c|c|c|c|c|c|c|c|c|c|c|c|}
\hline & & & & & & & \multirow{2}{*}{\multicolumn{4}{|c|}{ Moruno }} & \multirow{2}{*}{\multicolumn{5}{|c|}{ De la pera }} & \multirow{3}{*}{$\begin{array}{l}\text { Valenciano } \\
\text { Valenciano }\end{array}$} \\
\hline \multirow{2}{*}{$\begin{array}{l}\text { SSR } \\
\text { marker }\end{array}$} & \multirow{2}{*}{$\begin{array}{c}\text { Allele } \\
\text { (bp) }\end{array}$} & \multicolumn{5}{|c|}{ Muchamiel } & & & & & & & & & & \\
\hline & & 4 & 11 & 18 & 29 & 30 & 207 & 208 & 209 & 232 & 5 & 16 & 19 & 22 & 25 & \\
\hline \multirow[t]{2}{*}{ LELE25 } & A 248 & + & + & + & + & + & + & + & + & + & & & & & & + \\
\hline & В 250 & & & & & & & & & & + & + & + & + & + & \\
\hline \multirow[t]{2}{*}{ LEMDDNa } & A 246 & & & & & & & & & & & & + & + & & \\
\hline & В 252 & + & + & + & + & + & & & & & + & + & & & + & \\
\hline \multirow{3}{*}{ LESSF } & C 255 & & & & & & + & + & + & + & & & & & & + \\
\hline & A 335 & & & & & & & & & & & & & & & + \\
\hline & В 340 & + & + & + & + & + & + & + & + & + & + & + & + & + & + & \\
\hline
\end{tabular}

Although the main tomato types could be distinguished, the SSR profiles using the 10 markers were identical for several cultivars within the same type. Thus, we were not able to distinguish 'Much4' from 'Much11', 'Much18' from 'Much29', 'Pera6' from 'Pera25', 'Pera19' from 'Pera22', and 'Baladre' from 'Mor207'. Cultivars within the main types clearly have a common origin, but they present important differences in fruit shape, yield, fruit weight, among other traits (unpublished data). However, in tomato, due to the narrow genetic base of the cultivars, it is usually difficult to detect these differences using molecular markers, as it has been the case for the SSR markers used in the present study. Also, Nesbitt and Tanksley (2002) found no allelic diversity among four esculentum cultivars in part of the DNA sequence of the $f w 2.2$ gene, currently the only cloned locus that is known to be involved in the domestication of tomato fruit. In the present study, the SRAP marker system was able to detect variability among all the accessions within each type, probably due to its moderate multiplexing ability and a good coverage of the genome (Li and Quiros, 2001).

\section{Cluster and principal coordinates analysis}

The grouping of the accessions obtained with the two marker systems was rather similar (Figs. 2 and 3), although the bootstrap support of SRAP clusters was much higher than that of the tree made with SSR data, which is probably due in part to the higher number of data provided by the SRAP system. Another difference is that genetic similarities are much higher when calculated with the SRAP data, a expected result since this marker system detects preferentially polymorphisms in coding sequences, which have a mutation rate much lower than that of the microsatellite regions.

The De la pera cultivars were always grouped in a clearly separated cluster, suggesting that they are very closely related. This result was not unexpected, since these cultivars come from a rather small area. Cultivars of the Muchamiel type, that come from a wider geographic area, were also grouped together with SSR markers, and clearly separated from the De la pera group, but they formed two separate clusters with the SRAP markers. The four cultivars of the Moruno type that also come from a wide area appear in different groups in both dendograms. This result suggests that the denomination Moruno, based on the dark red color of their epidermis and even the flesh, is an ambiguous classification that is not based on real genetic similarity. The cultivar Valenciano appears in the two dendograms very close to 'Mor207', but the grouping of the 'Baladre' accession is unclear, since it has the same SSR profile as 'Mor207, but is grouped with 'Mor209' and 'Mor232' in the SRAP tree.

The hybrid 'Anastasia' and the breeding line EPSO42 share genetic resistances to the tomato mosaic virus (ToMV), tomato spotted wilt virus (TSWV), and tomato yellow leaf curl virus (TY- 


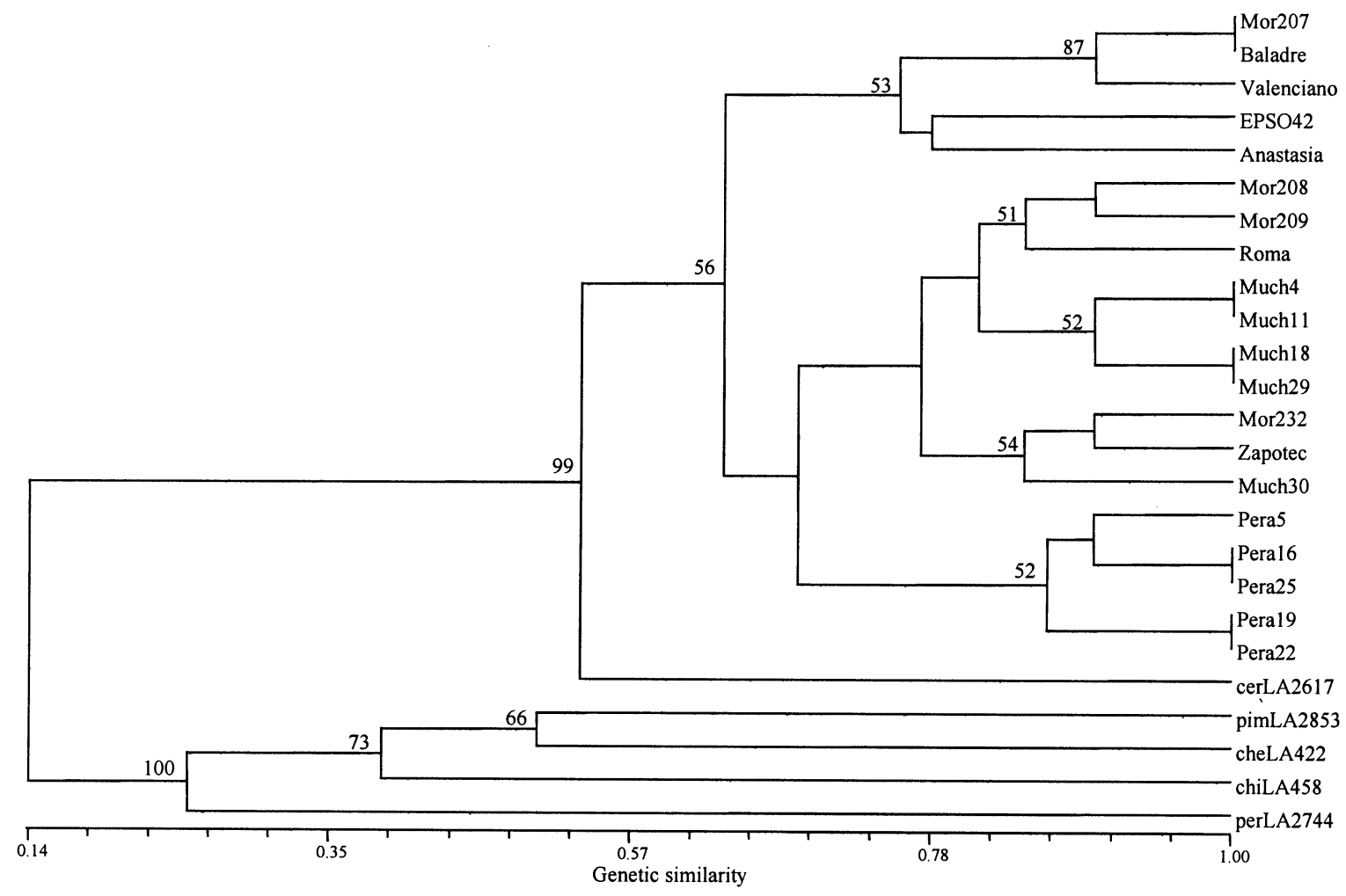

Fig. 2. Dendrogram showing the relationships among 20 accessions of cultivated tomato and five wild species using simple sequence repeat (SSR) markers, based on Nei and $\mathrm{Li}$ (1979) distance and the unweighted pair-group method (UPGMA) cluster analysis method. Percentages of 1000 bootstrap replications are given for nodes with bootstrap values $>50 \%$.

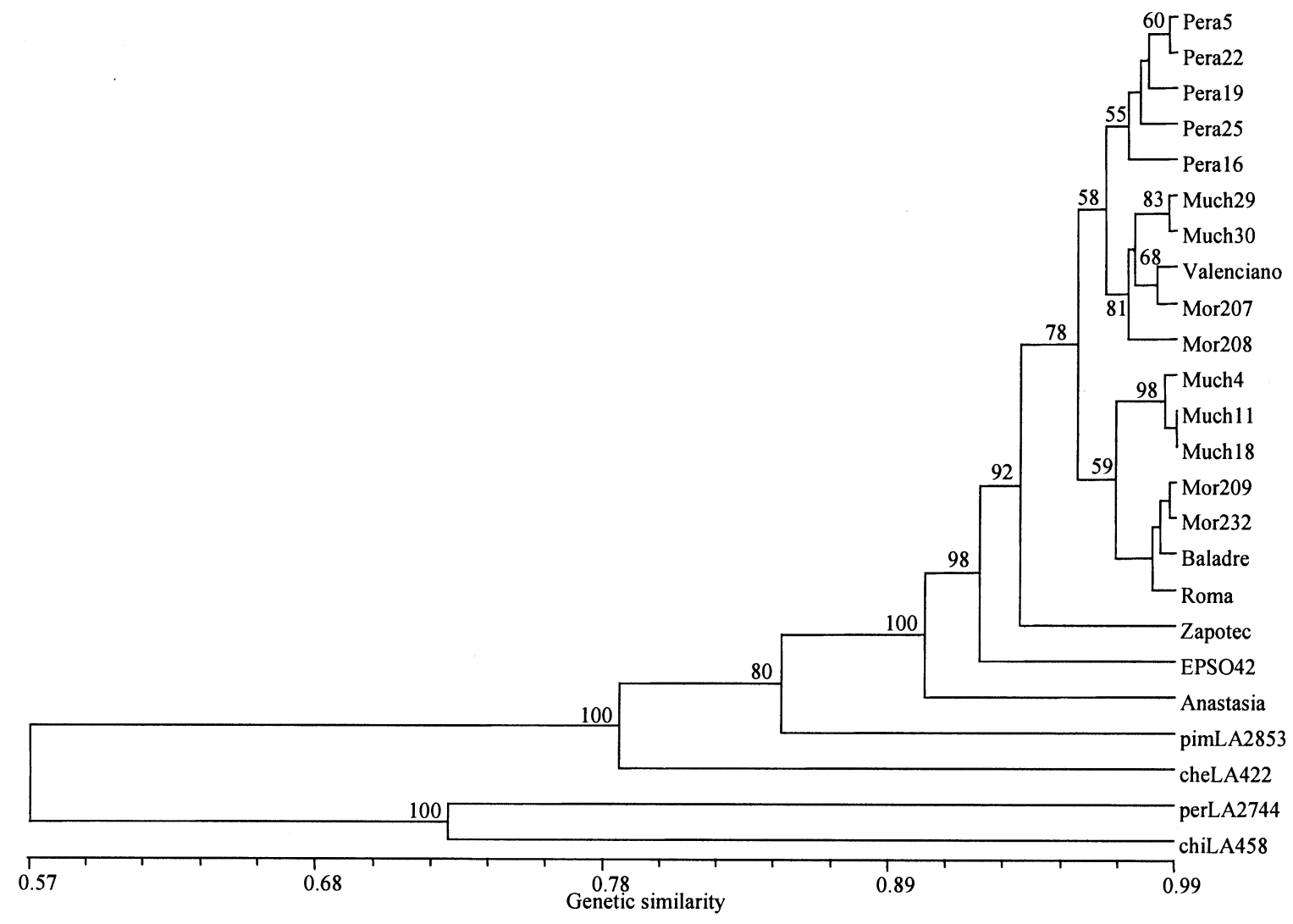

Fig. 3. Dendrogram showing the relationships among 20 accessions of cultivated tomato and four wild species using sequence related amplified polymorphism (SRAP) markers, based on Nei and Li (1979) distance and the unweighted pair-group method UPGMA cluster analysis method. Percentages of 1000 bootstrap replications are given for nodes with bootstrap values $>50 \%$. 
LCV), so both share chromosomal segments recently introgressed from the wild species $L$. chilense and L. peruvianum (Pico et al., 2002). However, 'Anastasia' has more resistance genes (it is also resistant to Verticillium Nees and Fusarium oxysporum Schlecht.) indicating that it has more introgressed wild chromosomal segments than EPSO42. The similarities between both accessions was detected by both marker systems, but seems to be better resolved by the SRAP than by the SSR system (Figs. 2 and 3). The tree based on SRAP data clearly separates the hybrid 'Anastasia' and the breeding line EPSO42 from the group of traditional cultivars, and place these two genotypes near the wild species. In addition, the Mexican cultivar Zapotec is also clearly separated from the European local cultivars in the SRAP tree but not so in the SSR tree. In fact, in the SRAP tree the accessions seem to be ordered from "more wild" to "more domesticated," although there are no clear evidence to affirm that the European local cultivars are more domesticated than 'Zapotec'.

Similar general conclusions can be drawn from the PCoA. For SSR data, the two first principal coordinates of PCoA account for $18.7 \%$ and $13.4 \%$ of the total variation, respectively. The first coordinate separate the wild Lycopersicon species from the cultivated cultivars, with the cerasiforme accession in an intermediate position. Similar results are observed in the PCoA of the SRAP data, but unfortunately the cerasiforme accession was not included in the analysis. The De la pera cultivars are closely grouped, while the Muchamiel cultivars are more loosely grouped. In a graphic multivariate analysis performed with phenotypic fruit traits $[\mathrm{Fe}, \mathrm{Cu}, \mathrm{Mn}$, and $\mathrm{Zn}$ content, maturity index (soluble solids concentration/total acidity) and chroma] in several cultivars of the Muchamiel and De la pera types (Ruiz et al., 2004), the cultivars Pera 16 and Much30 were the genotypes most separated from their respective groups. The same effect can be observed using both SSR and SRAP molecular markers (Figs. 2 and 3).

In conclusion, as few as three selected SSR markers were sufficient to differentiate among the three main traditional cultivar types, confirming that these markers are suitable for a species like tomato, which has low levels of variation. However, using all the selected SSR markers we were not able to differentiate cultivars of the same type but with clearly different phenotypes. It should be considered that SSR development is expensive and time consuming, and that the SSR markers used had been specifically selected for tomato cultivar characterization among a high number of markers. All cultivars could be differentiated using SRAP markers. They are mostly dominant markers and less polymorphic than SSR, but have a higher multiplexing ratio, and previous development efforts are not necessary. The SRAPmarkers used in the present study had not been selected for tomato. Then, they can be an alternative to SSR in studies of genetic variability and relationships among cultivars, mainly in crop species not so deeply investigated as the tomato.

Several closely related traditional cultivars of tomato have been typified using two marker systems with different characteristics. This information would be useful to facilitate tomato germplasm conservation and management efforts.

\section{Literature Cited}

Alonso, A., S. García-Martínez, M. Valero, P. Blasco, J.J. Ruiz, and F. Ruiz-Beviá. 2003 Análisis cuantitativo de compuestos volátiles responsables del aroma en variedades tradicionales de tomate. Actas de Horticultura 39:73-76.

Alvarez, A.E., C.C.M. Van de Wiwl, M.J.M. Smulders, and B. Vosman. 2001. Use of microsatellites to evaluate genetic diversity and species relationships in the genus Lycopersicon. Theor. Appl. Genet. 103:1283-1292.

Bredemeijer, G.M.M., P. Arens, D. Wouters, D. Visser, and B. Vosman. 1998. The use of semi-automated fluorescent microsatellite analysis for tomato cultivar identification. Theor. Appl. Genet. 97:584-590

Bredemeijer, G.M.M., R.J. Cooke, M.W. Ganal, R. Peeters, P. Isaac, Y. Noordijk, S. Rendell, J. Jackson, M.S. Röder, K. Wndehake, M. Dijcks, M. Amelaine, V. Wickaert, L. Bertrand, and B. Vosman. 2002. Construction and testing of a microsatellite database containing more than 500 tomato varieties. Theor. Appl. Genet. 105:1019-1026.

Dellaporta, S.L., J. Wood, and J.B. Hicks. 1983. A plant DNA minipreparation: Versión II. Plant Mol. Biol. Rpt. 4:19-21.

Felsenstein, J. 1993. PHYLIP (Phylogeny Inference Package) version 3.6a2. Dept. of Genetics. Univ. of Washington. Seattle.

Ferriol, M., B. Picó, and F. Nuez. 2004. Morphological and molecular diversity of a collection of Cucurbita maxima landraces. J. Amer. Soc. Hort. Sci. 129:60-69.

He, C., V. Poysa, and K. Yu. 2003. Development and characterization of simple sequence repeat (SSR) markers and their use in determining relationships among Lycopersicon esculentum cultivars. Theor. Appl. Genet. 106:363-373.

Jenkins, J.A. 1948. The origin of the cultivated tomato. Econ. Bot. 2:379-392.

Li, G. and C.F. Quiros. 2001. Sequence-related amplified polymorphism (SRAP), a new marker system based on a simple PCR reaction: its application to mapping and gene tagging in Brassica. Theor. Appl. Genet. 103:455-461.

Li, G., M. Gao, B. Yang, and C.F. Quiros. 2003. Gene for gene alignment between the Brassica and Arabidopsis genomes by direct transcriptome mapping. Theor. Appl. Genet. 107:168-180.

Nei, M. and W. Li. 1979. Mathematical model for studying genetic variation in terms of restriction endonucleases. Proc. Natl. Acad. Sci. USA 79:5269-5273.

Nesbitt, T.C. and S.D. Tanksley. 2002. Comparative sequencing in the genus Lycopersicon: Implications for the evolution of fruit size in the domestication of cultivated tomatoes. Genetics 162:365-379.

Nuez, F., G. LLacer, and J.J. Ruiz. 2002. Horticulture in Spain. Chronica Hort. 42:25-29.

Picó, B., J. Herraiz, J.J. Ruiz, and F. Nuez. 2002. Widening the genetic basis of virus resistance in tomato. Scientia Hort. 94(1-2):73-89.

Rick, C. M. 1976. Tomato, p. 268-273. In: N.W. Simmonds (ed.). Evolution of crop plants. Longman, London.

Rohlf, F.J. 1998. NTSYS-pc: Numerical taxonomy and multivariate analysis system, version 2.0, user guide. Exeter Software, New York.

Ruiz, J.J., B. Picó, G. Li, V. D’Antonio, B. Falk, and C.F. Quiros. 2001. Identification of markers linked to a celery mosaic virus resistance gene in celery. J. Amer. Soc. Hort. Sci.126:432-435.

Ruiz, J.J., N. Martínez, M. Valero, S. García-Martínez, R. Moral, and M. Serrano. 2004. Micronutrient composition and quality characteristics of traditional tomato cultivars in the south-east of Spain. Commun. in Soil Sci. \& Plant Anal. (In press).

Smulders, M.J.M., G. Bredemeijer, W. Rus-Kortekaas, P. Arens, and B. Vosman. 1997. Use of short microsatellites from database sequences to generate polymorphisms among Lycopersicon esculentum cultivars and accessions of other Lycopersicon species. Theor. Appl. Genet. 97:264-272.

Sneath, P.H.A. and R.R. Sokal. 1973. Numerical taxonomy. The principles and practice of numerical classification. Freeman, San Francisco. 